\title{
Cellulase stability, adsorption/desorption profiles and recycling during successive cycles of hydrolysis and fermentation of wheat straw
}

\author{
Ana Cristina Rodrigues ${ }^{\mathrm{a}}$, Claus Felby ${ }^{\mathrm{b}}$, Miguel Gama ${ }^{\mathrm{a}, *}$ \\ ${ }^{a}$ Centro de Engenharia Biológica, Universidade do Minho, Campus de Gualtar, 4710-057 Braga, Portugal \\ ${ }^{\mathrm{b}}$ Department of Geosciences and Natural Resource Management, University of Copenhagen, Rolighedsvej 23, DK-1958 Frederiksberg C, Denmark
}

\section{H I G H L I G H T S}

- Characterization of the enzyme distribution between the liquid and solid fractions.

- More efficient hydrolysis leads to higher recovery in the liquid fraction.

- Enzyme recycling critically depends on thermostability.

- Appropriated choice of the process conditions may lead to efficient enzyme recycling.

\section{A R T I C L E I N F O}

Article history:

Received 13 October 2013

Received in revised form 3 January 2014

Accepted 6 January 2014

Available online 17 January 2014

\section{Keywords:}

Cellulase

Adsorption/desorption

Thermo-stability

Recycling

\begin{abstract}
A B S T R A C T
The potential of enzymes recycling after hydrolysis and fermentation of wheat straw under a variety of conditions was investigated, monitoring the activity of the enzymes in the solid and liquid fractions, using low molecular weight substrates. A significant amount of active enzymes could be recovered by recycling the liquid phase. In the early stage of the process, enzyme adsorb to the substrate, then gradually returning to the solution as the saccharification proceeds. At $50^{\circ} \mathrm{C}$, normally regarded as an acceptable operational temperature for saccharification, the enzymes (Celluclast) significantly undergo thermal deactivation. The hydrolysis yield and enzyme recycling efficiency in consecutive recycling rounds can be increased by using high enzyme loadings and moderate temperatures. Indeed, the amount of enzymes in the liquid phase increased with its thermostability and hydrolytic efficiency. This study contributes towards developing effective enzymes recycling strategies and helping to reduce the enzyme costs on bioethanol production.
\end{abstract}

(c) 2014 Elsevier Ltd. All rights reserved.

\section{Introduction}

Bioethanol derived from the bioconversion of lignocellulosic feedstocks continues to attract global interest as an alternative to current petroleum-based fuels. However, considerable technical improvements are still needed before efficient and economically feasible lignocellulosic biomass-based ethanol processes can be commercialized. One of the major limitations of this process is the consistently high cost of the enzymes involved in the conversion of cellulose into fermentable sugars (Lynd et al., 2008; Klein-Marcusschamer et al., 2012).

Several strategies, such as increasing substrate reactivity through lignin removal or modification (Zhu et al., 2009a; Kumar et al., 2011) and enzyme recycling have been investigated (Otter et al., 1984, 1989; Tu et al., 2007a,b, 2009; Zhu et al., 2009b; Wu et al., 2010; Qi et al., 2011; Rodrigues et al., 2012; Lindedam

\footnotetext{
* Corresponding author. Tel.: +351 253604 400; fax: +351 253678986.

E-mail addresses: ana_cris@deb.uminho.pt (A.C. Rodrigues), cf@life.ku.dk (C. Felby),fmgama@deb.uminho.pt (M. Gama).
}

et al., 2013; Seo et al., 2011). After enzymatic hydrolysis, cellulases can either remain bound to the residual biomass (solid fraction) or free in the supernatant (liquid fraction) (Tu et al., 2009; Yang et al., 2010; Pribowo et al., 2012; Lindedam et al., 2013). Therefore, the studies on the cellulases adsorption, desorption, and re-adsorption are important to provide fundamental understanding regarding the potential of cellulase recycling.

Two overall complementary strategies to recover cellulases may be conceived, one regarding the fraction of enzyme present in the liquid phase, the other the solid bound fraction. In this work, we focus mainly on the first approach. Free cellulases in bulk solution may be recovered by promoting its readsorption on fresh substrate, which may include or not an ultrafiltration step (Lindedam et al., 2013; Qi et al., 2011; Lee et al., 1995; Knutsen and Davis, 2004). Regarding the solid bound fraction, recycling the residual lignin with the adsorbed enzyme is an attractive approach, given its simplicity. However, the solid lignin residue increases with the number of recycling rounds, adversely impacting the hydrolysis of fresh substrate (Girard and Converse, 1993; Lee et al., 1995). Enzymes bound to the solid residue may also be recovered by using 
agents such as surfactants, alkali, urea, glycerol, polyethylene glycol and buffers of different pH's (Rad and Yazdanparast, 1998; Otter et al., 1989; Rodrigues et al., 2012; Zhu et al., 2009b; Desphande and Erikson, 1984; Sipos et al., 2010; Wang et al., 2012).

It is important to recognize that recycling enzymes, an highly desirable goal, is possible only as long as they are stable through several cycles (Tengborg et al., 2001; Pribowo et al., 2012; Rodrigues et al., 2012; Chylenski et al., 2012). It has been observed that along hydrolysis and fermentation enzymes loose activity, an effect critically dependent on temperature (Rodrigues et al., 2012; Chylenski et al., 2012; Gunjikar et al., 2001; Ye et al., 2012). In previous work we observed that incubation for 1 week at $50{ }^{\circ} \mathrm{C}$ reduces the activity of Cel7A by 62.5\% (Rodrigues et al., 2012). Therefore, the use of thermostable enzymes - or operational conditions not compromising the enzymes stability - offer potential benefits in the hydrolysis of lignocellulosic substrates: enhanced stability allows for improved hydrolysis and increased flexibility with respect to process configurations, all leading to improvement of the overall economy of the process and increasing the potential for enzyme recycling.

This study describes the adsorption and activity profiles of specific enzymes present in Celluclast (Cel7A and Cel7B and $\beta$-glucosidase) during consecutive stages of hydrolysis and fermentation of pretreated wheat straw, using different hydrolysis temperature and enzyme loadings. In particular, the partition of enzyme between the solid and liquid fraction is analysed by monitoring the activity in each fraction by using low molecular weight substrates. Furthermore on basis of these results the second aim of this work was to determine whether by recycling the liquid fraction a significant amount of enzyme could be reused, and therefore increase overall product yields or decrease the amount of required enzyme needed to reach a given level of conversion.

\section{Methods}

\subsection{Enzymes and substrate}

Enzymatic hydrolysis was carried out using enzyme preparations, Celluclast 1.5 FG L combined with $\beta$-glucosidase (Novozyme 188) (all from Novozymes A/S, Bagsvaerd, Denmark). Wheat straw was processed by hydrothermal pretreatment at the Inbicon pilot plant (Petersen et al., 2009) and stored at $4{ }^{\circ} \mathrm{C}$. The pretreated wheat straw, used as substrate in the experiments, contained $52.82 \%$ cellulose, $2.47 \%$ xylan, $39.03 \%$ lignin Klason and $3 \%$ ash, as determined by acid hydrolysis (Section 2.4.3).

\subsection{Hydrolysis, fermentation and desorption}

The hydrolysis and fermentation were conducted under different conditions of temperature and enzyme loading, as described below.

Hydrolysis and fermentation were performed in $500 \mathrm{~mL}$ Erlenmeyer flasks in an incubator shaker (Unimax 1010 Heidolph) with a rotational mixing at $160 \mathrm{rpm}$. Enzymatic hydrolysis was carried out on $150 \mathrm{~mL}$ of $0.1 \mathrm{M}$ sodium acetate buffer (NaAc, SigmaAldrich, 32318) at $\mathrm{pH} 4.8$, using a concentration of biomass (wheat straw) of $5 \%(\mathrm{w} / \mathrm{v})$ on a dry weight basis. Celluclast was added at two different loadings, 20 and 40 Filter Paper Units (FPU)/g cellulose, supplemented with $\beta$-glucosidase to $40 \mathrm{IU} / \mathrm{g}$ cellulose.

Hydrolysis of the biomass was performed at $37^{\circ} \mathrm{C}$ or $50{ }^{\circ} \mathrm{C}$ for $48 \mathrm{~h}$. Afterwards, the fermentation flasks were cooled down to room temperature and inoculated with Saccharomyces cerevisiae CEN PK 113 wild type with an initial optical density (O.D.600 $)=0.1$. Other nutrients required for the fermentation stage were added to a final concentration of $1 \%(\mathrm{w} / \mathrm{v})$ yeast extract and
$2 \%(\mathrm{w} / \mathrm{v})$ peptone. The flasks were then incubated at $37^{\circ} \mathrm{C}$ for $120 \mathrm{~h}, 160 \mathrm{rpm}$. All the experiments were carried out under sterile conditions. Samples were taken at the beginning of the assay and every $24 \mathrm{~h}$, up to $168 \mathrm{~h}$, centrifuged at $4480 \mathrm{~g}$ for $12 \mathrm{~min}$ (microcentrifuge Sigma, model 113) and the supernatant was analysed for ethanol and sugars by HPLC (Section 2.4.4.). The enzymatic activities associated to liquid and solid fraction as well as the total activity were measured along the process, every $24 \mathrm{~h}$ (Section 2.4.1), in order to evaluate the adsorption/desorption profiles along hydrolysis/fermentation and the thermo stability of Celluclast.

Several consecutive rounds of hydrolysis/fermentation were performed using the recycled enzyme (Section 2.3). At the end of each round, the solid residue was separated from the liquid fraction by centrifugation at $13,131 \mathrm{~g}$ for $30 \mathrm{~min}$ (Sigma $4 \mathrm{~K} 15$ ), the supernatant was collected for additional treatment and subsequent recycling (described below) and the final solid residue composition was analysed for estimation of the biomass degree of conversion (Section 2.4.3).

\subsection{Cellulase recycling after each round of hydrolysis and fermentation of wheat straw}

The recovery of cellulases after fermentation was performed by filtering the liquid phase through a $0.22 \mu \mathrm{m}$ Polyethersulfone (PES) Membrane ACROVAC (PALLAVFP02S) followed by concentration and buffer exchanging with fresh $0.1 \mathrm{M}$ NaAc buffer, $\mathrm{pH} 4.8$ in a tangential ultrafiltration system Pellicon XL membrane with a $10 \mathrm{kDa}$ cut-off PES membrane (Millipore, Billerica, MA, USA). The recovered cellulase, buffer and nutrients were then added to fresh wheat straw substrate, at $5 \%(\mathrm{w} / \mathrm{v})$ on a dry weight basis to carry out the next round of hydrolysis and fermentation. At each new recycling round, fresh enzyme was added, corresponding to $20 \%$ of initial load of each enzyme, i.e. 4 FPU Celluclast: 8 IU $\beta$-glucosidase/g cellulose and $8 \mathrm{FPU}$ Celluclast: $8 \mathrm{IU} \quad \beta$-glucosidase $/ \mathrm{g}$ cellulose, in order to compensate the enzyme lost (either due to deactivation or some loss of material in the manipulation of the samples, namely in the ultrafiltration stage). The conditions (time, temperature, mixing) of hydrolysis and fermentation, time point for sample collected and analysis of two consecutive rounds of enzyme recycling (R1) and (R2) were the same as in the first stage of fermentation (R0).

\subsection{Analytical methods}

\subsubsection{Enzyme activity measurements}

Cel7A, Cel7B and $\beta$-glucosidase activities were measured by fluorescence spectroscopy using a Biotech Synergy HT Elisa plate reader and 4-methylumbelliferyl- $\beta$-D-cellobioside (MUC, Sigma-Aldrich, M6018), 4-methylumbelliferyl- $\beta$-D-lactopyranoside (MULac, Sigma-Aldrich, M2405) and 4-methylumbelliferyl- $\beta$ D-glucopyranoside (MUGlc, Sigma-Aldrich, M3633) as substrates, respectively. Upon hydrolysis by Cel7A, Cel7B and $\beta$-glucosidase, the substrates release free 4-methylumbelliferone (MU, SigmaAldrich, M1508) resulting in a shift of the fluorescence spectra (excitation maximum/fluorescence maximum), which was quantified for excitation and emission wavelengths of 360 and $460 \mathrm{~nm}$ respectively.

The Cel7A, Cel7B and $\beta$-glucosidase activities were measured by adjusting the protocol published by Bailey and Tähtiharju (2003). In these assays, $400 \mu \mathrm{L}$ of $1 \mathrm{mM}$ MUC, MULac or MUGlc solutions (in $0.1 \mathrm{M} \mathrm{NaAc}$ buffer, $\mathrm{pH} 4.8$ ) were added to $50 \mu \mathrm{L}$ of the test samples (dilutions in NaAc buffer); the mixture was vortexed and incubated at $50{ }^{\circ} \mathrm{C}$ for $15 \mathrm{~min}$. The reaction was then stopped by addition of $550 \mu \mathrm{L} 1.0 \mathrm{M} \mathrm{Na}_{2} \mathrm{CO}_{3}$ buffer (Panreac, 131647.1211) (for Cel7A and $\beta$-glucosidase activity 
measurements) or $500 \mu \mathrm{L} \quad 1.0 \mathrm{M} \quad \mathrm{Na}_{2} \mathrm{CO}_{3}$ buffer (Panreac, 131647.1211) (for Cel7B activity measurements) and measured on a black bottom 96-well UV fluorescence microplate. Since Cel7A, Cel7B and $\beta$-Glucosidase - all hydrolyse the MULac substrate, the Cel7B activity was measured adding $50 \mu \mathrm{L}$ of a mixture containing $1.0 \mathrm{M}$ glucose and $50 \mathrm{mM}$ cellobiose to the chromophoric substrate MULac, in order to inhibit the Cel7A and $\beta$-glucosidase activities (van Tilbeurgh et al., 1982).

A $1 \mathrm{mM}$ stock solution of MU was diluted from $0.0001 \mathrm{mM}$ to $0.02 \mathrm{mM}$ and used to prepare a standard calibration curve by plotting MU concentration ( $\mathrm{mM}$ ) versus relative fluorescence units (RFU). The amounts of MUC, MULac and MUGlc hydrolyzed (mM) were converted to enzyme activity units, (IU/mL), defined as the amount of enzyme that catalyzes the transformation of one micromole of substrate per minute under specified conditions. The amount of MUC, MULac or MUGlc hydrolyzed was determined using the calibration curves obtained. All assays were performed in triplicate.

\subsubsection{Activity on filter paper fibers - FPase assay}

The filter paper activity of the liquid fractions collected at the beginning and at the end of the process (before ultrafiltration) was measured.

The Cellulase activity was expressed in FPU in accordance with the standard analytical methods established by the National Renewable Energy Laboratory (Adney and Baker, 1996). One unit of filter paper cellulase activity (FPU) was defined as the amount of enzyme which produces $2.0 \mathrm{mg}$ of reducing sugar from $50 \mathrm{mg}$ of filter paper within $1 \mathrm{~h}$. The experiment was carried out in a reaction mixture containing $0.5 \mathrm{~mL}$ of diluted samples enzyme solution, $1.0 \mathrm{~mL}$ of $0.1 \mathrm{M} \mathrm{NaAc}$ buffer ( $\mathrm{pH} 4.8$ ), and $50 \mathrm{mg}$ of a $1 \times 6 \mathrm{~cm}$ strip of a Whatman No. 1 filter paper. The reaction solution was incubated at $50{ }^{\circ} \mathrm{C}$ for $1 \mathrm{~h}$. Then the concentration of the released reducing sugar was measured using the 3,5-dinitrosalicylic acid (DNS) method (Miller, 1959).

\subsubsection{Analysis of the composition of the solid residue}

The solid residue obtained after hydrolysis and fermentation was dried at $37^{\circ} \mathrm{C}$ to constant weight. Aliquots from the homogenized residue lot were subjected to moisture determination and quantitative acid hydrolysis with $5 \mathrm{~mL}$ of $72 \%$ (w/w) sulphuric acid for $1 \mathrm{~h}$ at $30^{\circ} \mathrm{C}$, with constant stirring, followed adding water until $148.67 \mathrm{~g}$ and autoclaved at $121^{\circ} \mathrm{C}$ for $1 \mathrm{~h}$. Thereafter, the solid residue from hydrolysis process was recovered by filtration with crisol Gooch $n^{\circ} 3$ and drying at $105^{\circ} \mathrm{C}$ to constant weight; this residue was classified as Klason lignin (Browning, 1967). The monosaccharides in the liquid fraction were analysed by HPLC (Section 2.4.4).

\subsubsection{Sugar and ethanol analysis}

All liquid samples taken from the hydrolysis and fermentation were filtered through a $0.2 \mu \mathrm{m}$ (PES membrane, $\varnothing 25 \mathrm{~mm}$, VWR 514-0072) and analysed for cellobiose, glucose and ethanol by HPLC. Chromatographic separation was performed using a Metacarb $87 \mathrm{H}$ column $(300 \times 7.8 \mathrm{~mm}$, Varian, USA $)$ under the following conditions: mobile phase $0.005 \mathrm{M} \mathrm{H}_{2} \mathrm{SO}_{4}$, flow rate $0.7 \mathrm{~mL} / \mathrm{min}$, and column temperature $60^{\circ} \mathrm{C}$. The volume injected was $20 \mu \mathrm{L}$. The concentration of monosaccharides and ethanol were determined based on calibration curves of these pure compounds.

\subsection{Calculations}

\subsubsection{Glucose yield}

The glucose yield was calculated according to the NREL standard procedure (Down and McMillan, 2001):
$\%$ Yield $=\frac{[\text { Glucose }]+1.053 \times[\text { Cellobiose }]}{1.111 \times f \times[\text { Biomass }]} \times 100 \%$

where [Glucose] is the residual glucose concentration (g/L). [Cellobiose] is the residual cellobiose concentration $(\mathrm{g} / \mathrm{L})$. [Biomass] is the dry biomass weight concentration at the beginning of the hydrolysis step $(\mathrm{g} / \mathrm{L}) ; f$ is the cellulose fraction of dry biomass $(\mathrm{g} / \mathrm{g})$.

\subsection{Statistical analysis}

The statistical analyses were performed using GraphPad Prism version 5 for Windows, GraphPad Software, San Diego, California, USA.

\section{Results and discussion}

\subsection{Enzyme stability and distribution of enzymes in the liquid and solid fractions}

The thermal stability of cellulases (Cel7A and Cel7B) and $\beta$-glucosidase under the operational conditions was assessed, as this is of paramount importance in any enzyme recycling strategy. All three enzymes proved to be stable at $37^{\circ} \mathrm{C}$ ("total enzyme activity" data on Fig. 1A and C), as the activity observed is constant throughout the process, up to $168 \mathrm{~h}$, for each of the recycling rounds. However, when the hydrolysis was conducted at $50^{\circ} \mathrm{C}$, a significant reduction of enzymatic activity was observed in all cases ("total enzyme activity" data on Fig. 1B and D), particularly in the first $24 \mathrm{~h}$, but also steadily throughout the entire process. Interestingly, the loss of enzyme activity was in every case more pronounced in the initial round (R0). A plausible explanation is thermal denaturation, deactivation by shear forces or contact with the air-liquid interphase. Cel7A and Cel7B seems to be slightly less stable than $\beta$-glucosidase, as the fraction of total activity reduction is more expressive in this case ("total enzyme activity" data on Fig. 1B and $\mathrm{D}$ ).We have measured the activity of the different enzymes in the solid and liquid fractions along the process in order to analyse the effect of temperature and enzyme concentration on the distribution between the phases of the heterogeneous system and to define a suitable enzyme recycling strategy. In general, as expected and in accordance with many studies (Tu et al., 2009; Qi et al., 2011; Pribowo et al., 2012; Yang et al., 2010), we observed the adsorption of Cel7A and Cel7B, which was more pronounced at the initial phase of hydrolysis; at $24 \mathrm{~h}$, more enzyme activity is adsorbed than in solution, especially in the case a lower load of enzyme was used. Increasing the enzyme loading from 20 FPU to 40 FPU resulted in a reduction of the fraction of enzyme activity adsorbed after fermentation, likely because of the higher conversion degree and saturation of the substrate surface (Fig. 1A-D). After the initial $24 \mathrm{~h}$, enzymes desorbed continuously throughout the process, an effect more evident in the R0 round for the lower temperature. Therefore, at the end of fermentation, part of the active Cel7A and Cel7B remained attached to the final residue (Fig. 1A-D). Overall, the portion of enzyme adsorbed after $168 \mathrm{~h}$ seemed to increase as the cellulose conversion degree decreased, this being more evident in cases where the original enzyme loading was lower (Figs. 1 and 2). For example, under the conditions corresponding to Figs. $1 \mathrm{~A}$ and $2 \mathrm{~A}\left(20 \mathrm{FPU}\right.$, hydrolysis at $37^{\circ} \mathrm{C}$ ) the conversion degree after $48 \mathrm{~h}$ dropped from $80 \%$ in the initial round (R0) to $50.2 \%$ and $31 \%$ in the following ones (R1 and $\mathrm{R} 2$ ). The desorption of enzyme was quite high during the initial round (70\%), but not so expressive in the next ones (58\% R1 and $49 \%$ R2), both for Cel7A and Cel7B. A similar trend was observed under the other conditions (Figs. 1B-D and 2B-D). Noteworthy, under the most effective conditions ( $40 \mathrm{FPU}$, hydrolysis at $37^{\circ} \mathrm{C}$, Fig. $2 \mathrm{C}$ ), a high conversion degree was reached after $48 \mathrm{~h}$ in the consecutive 

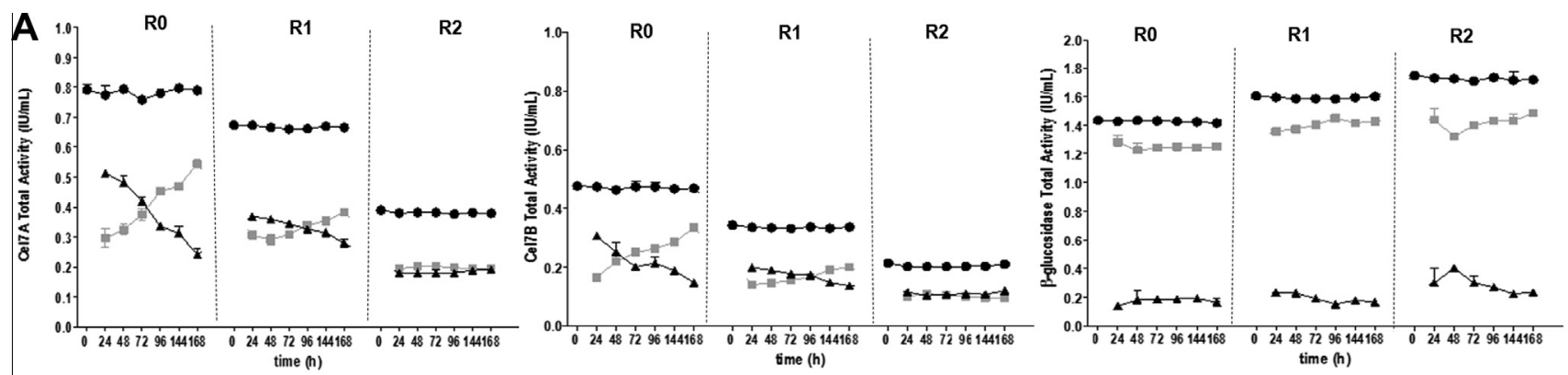

B
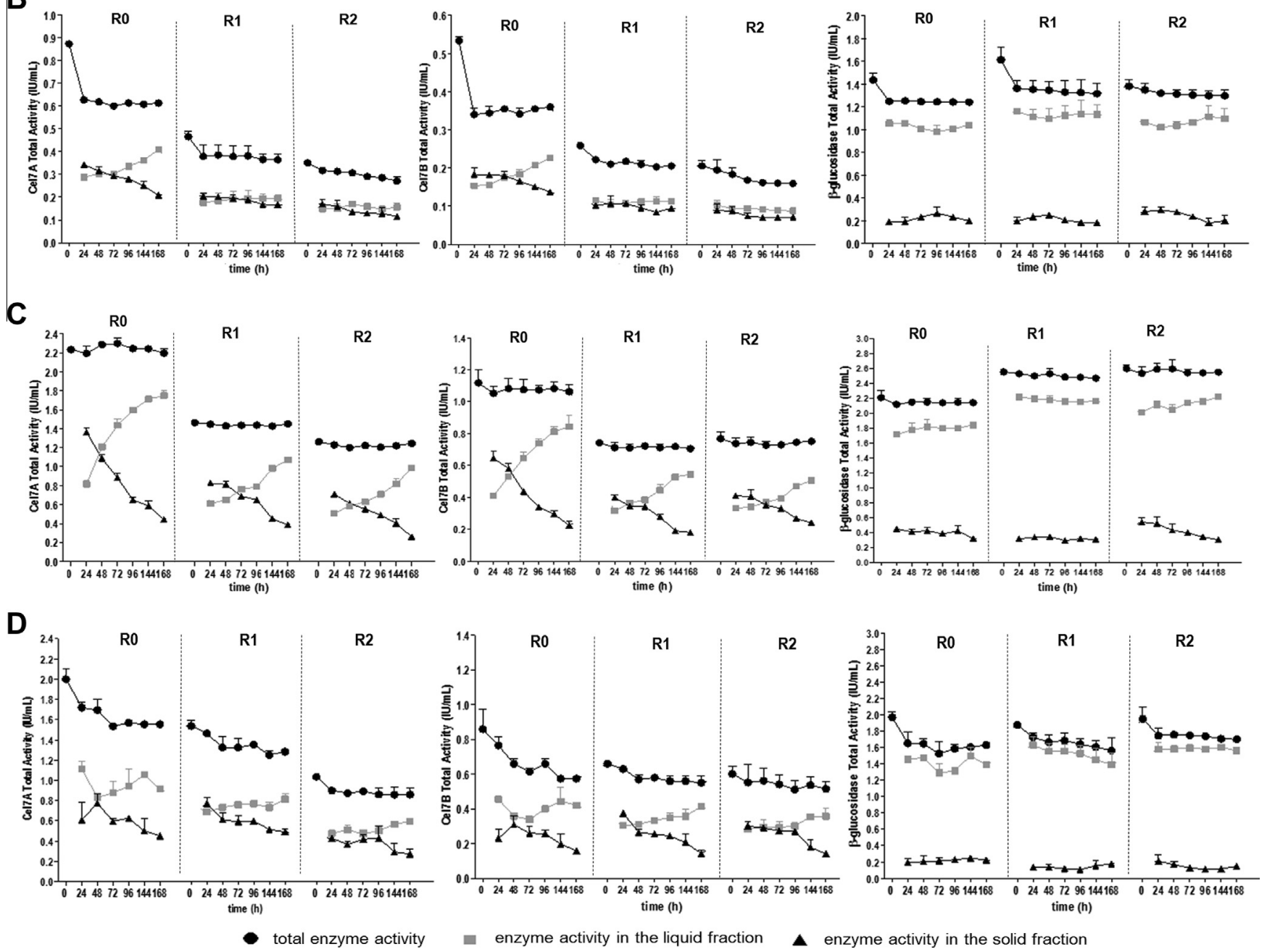

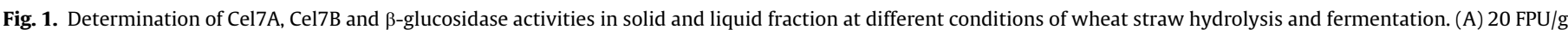

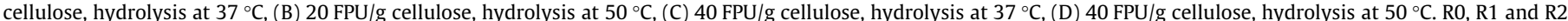

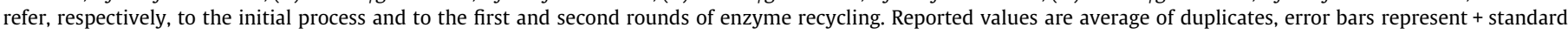
deviation.

rounds (respectively $100 \%, 89 \%$ and $81 \%$, for R0, R1 and R2), and in this case both Cel7A and Cel7B returned to the soluble phase after $168 \mathrm{~h}$ in higher amounts, in each round. It is remarkable that using $37{ }^{\circ} \mathrm{C}$ during hydrolysis results in a residual total activity at the end of R2 of about 1.2 and $0.75 \mathrm{IU} / \mathrm{mL}$ (Fig. 1C, total enzyme activity), respectively for Cel7A and Cel7B, higher than the observed activities for the case where a temperature of $50{ }^{\circ} \mathrm{C}$ has been used ( 0.86 and $0.52 \mathrm{IU} / \mathrm{mL}$ - Fig. 1D). This is certainly due to the thermal deactivation of enzymes, which is clearly not stable enough at $50{ }^{\circ} \mathrm{C}$. Another result that highlights the critical relevance of the temperature in the overall yield obtained according to the time course of the reaction: in the initial round (R0), although after the first $24 \mathrm{~h}$ the degradation of the lignocellulosic material was more efficient when using higher temperatures $(67 \%$ and $87 \%$ at $50{ }^{\circ} \mathrm{C}, 20$ and $40 \mathrm{FPU}$, respectively; $60 \%$ and $75 \%$ at $37{ }^{\circ} \mathrm{C}, 20$ and $40 \mathrm{FPU}$, respectively), after $48 \mathrm{~h}$ more efficient conversion rates were achieved using a lower temperature $\left(77 \%\right.$ and $97 \%$ at $50{ }^{\circ} \mathrm{C}$, 20 and $40 \mathrm{FPU}$, respectively; $80 \%$ and $100 \%$ at $37{ }^{\circ} \mathrm{C}$, and 20 and $40 \mathrm{FPU}$, respectively) (Fig. 2A-D R0). The significance of each results was examined using analysis of variance (ANOVA). For both enzyme loadings it was observed that the differences observed after $24 \mathrm{~h}$, comparing the hydrolysis yield at $37^{\circ} \mathrm{C}$, was indeed significant $(p<0.01)$. At the end of $48 \mathrm{~h}$ of hydrolysis, the difference between two temperatures used is still significant, with $p<0.05$. As we have shown in previous work, cellulases have lower binding affinity to lignin as compared to pure cellulose (Rodrigues 



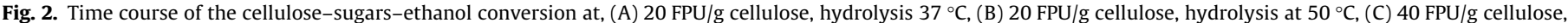

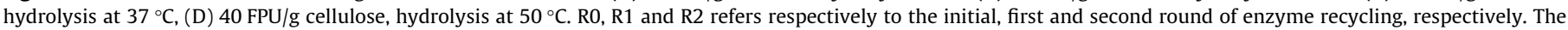
cellulose conversion degrees at $24,48 \mathrm{~h}$, (\%) are shown on the top of the graphs. Reported values are average of duplicates, error bars represent \pm standard deviation.

et al., 2012). Therefore, it seems that reaching a high conversion degree is helpful in allowing the enzyme to become available in the liquid fraction, which obviously makes it easier to be recovered. A distinct behaviour is observed in the case of $\beta$-glucosidase, which is poorly adsorbed by the substrate (Fig. 1A-D), certainly due to the absence of a cellulose-binding domain in this enzyme.

\subsection{Enzyme recovery}

The results discussed in the previous section indicate that a substantial amount of enzyme activity can be recovered from the liquid fraction (superior to about 70\%), provided a high conversion degree is achieved (as under the conditions corresponding to Fig. 1C). The soluble enzyme may be recovered by ultrafiltration. As shown in Table 1, about 20\% (between $11 \%$ and $29 \%$ of the initial load) of the enzyme is lost in this operation, thus we have added $20 \%$ of fresh enzyme in the rounds $\mathrm{R} 1$ and $\mathrm{R} 2$. Although a membrane with a cut off weight of $10 \mathrm{kDa}$ has been used, still some enzyme is lost due to filtration. Because, ultrafiltration process was conducted on relatively small samples in lab scale, the amount of material lost during handling, e.g. in the filtration device, becomes a large percentage. In an industrial scale loosing 
Table 1

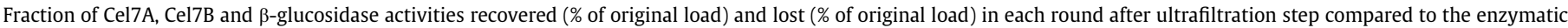
activity recovered in the liquid fraction after fermentation.

\begin{tabular}{|c|c|c|c|c|c|c|c|c|c|}
\hline \multirow[t]{2}{*}{ Enzyme } & \multirow[t]{2}{*}{ Round } & \multicolumn{2}{|c|}{$\begin{array}{l}20 \mathrm{FPU} / \mathrm{g} \text { cellulose, } 37^{\circ} \mathrm{C} \\
\text { prehydrolysis }\end{array}$} & \multicolumn{2}{|c|}{$\begin{array}{l}20 \mathrm{FPU} / \mathrm{g} \text { cellulose, } 50^{\circ} \mathrm{C} \\
\text { prehydrolysis }\end{array}$} & \multicolumn{2}{|c|}{$\begin{array}{l}40 \mathrm{FPU} / \mathrm{g} \text { cellulose, } 37^{\circ} \mathrm{C} \\
\text { prehydrolysis }\end{array}$} & \multicolumn{2}{|c|}{$\begin{array}{l}40 \mathrm{FPU} / \mathrm{g} \text { cellulose, } 57^{\circ} \mathrm{C} \\
\text { prehydrolysis }\end{array}$} \\
\hline & & $\begin{array}{l}\text { Enzyme } \\
\text { recovery (\% of } \\
\text { original load) }\end{array}$ & $\begin{array}{l}\text { Enzyme lost } \\
\text { (\% of original } \\
\text { load) }\end{array}$ & $\begin{array}{l}\text { Enzyme } \\
\text { recovery (\% of } \\
\text { original load) }\end{array}$ & $\begin{array}{l}\text { Enzyme lost } \\
\text { (\% of original } \\
\text { load) }\end{array}$ & $\begin{array}{l}\text { Enzyme } \\
\text { recovery (\% of } \\
\text { original load) }\end{array}$ & $\begin{array}{l}\text { Enzyme lost } \\
\text { (\% of original } \\
\text { load) }\end{array}$ & $\begin{array}{l}\text { Enzyme } \\
\text { recovery (\% of } \\
\text { original load) }\end{array}$ & $\begin{array}{l}\text { Enzyme lost } \\
\text { (\% of original } \\
\text { load) }\end{array}$ \\
\hline \multirow[t]{3}{*}{ Cel7A } & Initial(R0) & 55 & 20 & 33 & 29 & 66 & 16 & 38 & 18 \\
\hline & 1st round (R1) & 46 & 21 & 28 & 33 & 67 & 14 & 32 & 39 \\
\hline & 2nd round (R2) & 38 & 29 & 39 & 11 & 60 & 18 & 39 & 32 \\
\hline \multirow[t]{3}{*}{ Cel7B } & Initial(R0) & 54 & 24 & 31 & 28 & 60 & 20 & 42 & 14 \\
\hline & 1st round (R1) & 47 & 21 & 31 & 28 & 61 & 18 & 36 & 43 \\
\hline & 2nd round (R2) & 35 & 23 & 39 & 9 & 57 & 14 & 47 & 21 \\
\hline \multirow[t]{3}{*}{$\beta$-glucosidase } & Initial(R0) & 77 & 11 & 61 & 16 & 78 & 7 & 59 & 16 \\
\hline & 1st round (R1) & 77 & 14 & 67 & 6 & 73 & 14 & 69 & 8 \\
\hline & 2 nd round (R2) & 71 & 18 & 75 & 7 & 71 & 19 & 67 & 17 \\
\hline
\end{tabular}

enzymes due to material losses would naturally be a point of optimization. We believe that by using a lower MWCO and by operating at an industrial scale (where the loss of small amounts of sample has lower impact in the final recovery) better yields can be reached. It is interesting to note that the yield of activity recovery from the liquid fraction after ultrafiltration was much higher when lower temperatures of hydrolysis $\left(37^{\circ} \mathrm{C}\right)$ and high initial loading of enzyme (40 FPU) were used. Indeed, a final recovery of both Cel7A and Cel7B of about 60\% (from 57\% to $67 \%$ of the initial load) was obtained using those conditions (Table 1 R0, R1 and R2). Raising the hydrolysis temperature to $50{ }^{\circ} \mathrm{C}$ and $40 \mathrm{FPU}$ resulted in a drop of the recovery from liquid fraction of the enzyme to about $40 \%$, certainly due to the protein instability, which again resulted in lower substrate conversion (as discussed in the previous section). Consequently, less enzyme is recovered from liquid fraction due to inactivation and also because of higher adsorption to the solid residue. The effect of the hydrolysis temperature was confirmed by analysing the results obtained using 20 FPU.

Along with the recycling rounds, in particular for low enzyme loadings, higher amounts of enzyme remaining adsorbed on the solid fraction after fermentation are detectable. For example at $20 \mathrm{FPU}$ and $37^{\circ} \mathrm{C}$, the adsorbed Cel7A after fermentation raises from $30 \%$ of the original load at R0 to $48 \%$ at R2; similar results are observed for Cel7B (Fig. 1A). This is probably because of the lower conversion degrees in the successive rounds of hydrolysis/ fermentation. Indeed, as we have shown in a previous study (Rodrigues et al., 2012), Cel7A and Cel7B have higher affinity for cellulose than for lignin.

The enzyme activities shown in Table 1 were measured using low molecular weight substrates, specific for the different kinds of enzyme present in the mixture. In order to verify whether the recovered enzyme was fully functional - able to bind and hydrolyse insoluble cellulose fibres - a filter paper assay was carried out. Thus, it was observed that the enzyme recovered, retains its ability to bind and hydrolyse a fresh substrate. The results obtained generally confirm the previous discussion: a more significant reduction of activity is observed when a temperature of $50{ }^{\circ} \mathrm{C}$ is used during hydrolysis. In the case of the assay performed with $40 \mathrm{FPU}$ and a hydrolysis temperature of $37^{\circ} \mathrm{C}$, the values of FPase activity unexpectedly increased in the consecutive rounds, probably because the concentration of $\beta$-glucosidase also increased and this may have had a significant impact on the results obtained using this assay (Table 2).

\subsection{Time course of enzymatic hydrolysis}

The activity profile of the various enzymes over time under the different conditions was monitored. It has to be recognized that quite high enzyme loadings were used ( 20 and $40 \mathrm{FPU}$ ). This was a choice in this work, made under the rational that it may pay to use high enzyme loads as long as the enzymes are recycled. Using more enzyme allows of course for a more efficient cellulose hydrolysis, as can be seen in Fig. 2A-D. As pointed out already, the effective conversion of cellulose allowed in turn for more enzyme to return to the liquid fraction, consequently allowing its easier recycling.

All of the experimental conditions showed a successive decrease, after the initial round $\mathrm{R} 0$, in the glucose yields detected at the end of the hydrolysis period ( $48 \mathrm{~h}$ ) (Fig. 2A-D), an effect more severely observed for the assays carried out with 20 FPU. In spite of the enzyme deactivation observed at $50{ }^{\circ} \mathrm{C}$, the use of $40 \mathrm{FPU}$ affords for more effective conversion, as could be expected. Indeed, the residual Cel7A activity observed at $50{ }^{\circ} \mathrm{C}-40 \mathrm{FPU}$ (Fig. 1D R2), about $0.9 \mathrm{IU} / \mathrm{mL}$, is slightly higher than the activity at the beginning of the process for $37^{\circ} \mathrm{C}-20 \mathrm{FPU}$, about $0.8 \mathrm{IU} / \mathrm{mL}$ (Fig. 1A R0).

The analysis of the insoluble residues obtained under the different conditions (Table 3 ) revealed that the estimation of cellulose conversion on the basis of soluble sugar analysis is probably overestimated, as still some glucose was detected in all of the insoluble residues obtained, although the soluble sugar analysis indicated yields of conversion close to $100 \%$, in some cases, already at $48 \mathrm{~h}$ (Table 3). Only using $40 \mathrm{FPU}$ and $37^{\circ} \mathrm{C}$, during the hydrolysis stage,

Table 2


labelled $\left(^{*}\right)$ it has not been possible to measure the FPase activity.

\begin{tabular}{|c|c|c|c|c|c|c|c|c|}
\hline \multirow{2}{*}{$\begin{array}{l}\text { Conditions } \\
\text { Round } \\
\end{array}$} & \multicolumn{2}{|c|}{$\begin{array}{l}20 \mathrm{FPU} / \mathrm{g} \text { cellulose, } 37^{\circ} \mathrm{C} \\
\text { prehydrolysis }\end{array}$} & \multicolumn{2}{|c|}{$\begin{array}{l}20 \mathrm{FPU} / \mathrm{g} \text { cellulose, } 50^{\circ} \mathrm{C} \\
\text { prehydrolysis }\end{array}$} & \multicolumn{2}{|c|}{$\begin{array}{l}40 \mathrm{FPU} / \mathrm{g} \text { cellulose, } 37^{\circ} \mathrm{C} \\
\text { prehydrolysis }\end{array}$} & \multicolumn{2}{|c|}{$\begin{array}{l}40 \mathrm{FPU} / \mathrm{g} \text { cellulose, } 50^{\circ} \mathrm{C} \\
\text { prehydrolysis }\end{array}$} \\
\hline & $0 \mathrm{~h}(\mathrm{FPU} / \mathrm{mL})$ & $168 \mathrm{~h}(\mathrm{FPU} / \mathrm{mL})$ & $0 \mathrm{~h}(\mathrm{FPU} / \mathrm{mL})$ & $168 \mathrm{~h}(\mathrm{FPU} / \mathrm{mL})$ & $0 \mathrm{~h}(\mathrm{FPU} / \mathrm{mL})$ & $168 \mathrm{~h}(\mathrm{FPU} / \mathrm{mL})$ & $0 \mathrm{~h}(\mathrm{FPU} / \mathrm{mL})$ & $168 \mathrm{~h}(\mathrm{FPU} / \mathrm{mL})$ \\
\hline Initial(R0) & 0.89 & 0.74 & 0.81 & 0.55 & 1.51 & 1.27 & 1.39 & 1.09 \\
\hline 1 st round(R1) & 0.86 & 0.53 & 0.65 & 0.44 & 1.64 & 1.44 & 0.91 & 0.86 \\
\hline 2nd round(R2) & 0.62 & $1.98^{*}$ & 0.47 & $1.69^{*}$ & 1.95 & 1.29 & 0.83 & 0.59 \\
\hline
\end{tabular}

mmoles glucose equivalents released per minute averaged over $60 \mathrm{~min}$. 
Table 3

Composition of lignocellulosic solid residue (\% of dry weight) after hydrolysis and fermentation of wheat straw at different conditions.

\begin{tabular}{|c|c|c|c|c|c|c|c|c|}
\hline \multirow{2}{*}{$\begin{array}{l}\text { Conditions } \\
\text { Round }\end{array}$} & \multicolumn{2}{|c|}{$\begin{array}{l}20 \mathrm{FPU} / \mathrm{g} \text { cellulose, } 37^{\circ} \mathrm{C} \\
\text { prehydrolysis }\end{array}$} & \multicolumn{2}{|c|}{$\begin{array}{l}20 \mathrm{FPU} / \mathrm{g} \text { cellulose, } 50^{\circ} \mathrm{C} \\
\text { prehydrolysis }\end{array}$} & \multicolumn{2}{|c|}{$\begin{array}{l}40 \mathrm{FPU} / \mathrm{g} \text { cellulose, } 37^{\circ} \mathrm{C} \\
\text { prehydrolysis }\end{array}$} & \multicolumn{2}{|c|}{$\begin{array}{l}40 \mathrm{FPU} / \mathrm{g} \text { cellulose, } 50^{\circ} \mathrm{C} \\
\text { prehydrolysis }\end{array}$} \\
\hline & $\begin{array}{l}\text { \% Cellulose } \\
\text { (glucan) }\end{array}$ & $\begin{array}{l}\text { \% Lignin } \\
\text { Klason }\end{array}$ & $\begin{array}{l}\text { \% Cellulose } \\
\text { (glucan) }\end{array}$ & $\begin{array}{l}\text { \% Lignin } \\
\text { Klason }\end{array}$ & $\begin{array}{l}\text { \% Cellulose } \\
\text { (glucan) }\end{array}$ & $\begin{array}{l}\text { \% Lignin } \\
\text { Klason }\end{array}$ & $\begin{array}{l}\text { \% Cellulose } \\
\text { (glucan) }\end{array}$ & $\begin{array}{l}\text { \% Lignin } \\
\text { Klason }\end{array}$ \\
\hline Initial(R0) & 5.5 & 84.9 & 6.8 & 79.9 & 5.02 & 86.9 & 6.02 & 89.8 \\
\hline 1st round(R1) & 12.0 & 78.9 & 19.05 & 79.6 & 5.9 & 84.09 & 8.8 & 83.4 \\
\hline 2nd round(R2) & 26.05 & 65.9 & 31.1 & 58 & 9.4 & 80.2 & 12.3 & 77.4 \\
\hline
\end{tabular}

similar yields of cellulose conversion (Table 3) and ethanol (Fig. 2) were obtained throughout the 3 rounds, although the residual cellulose was a bit higher for R2 than in the other rounds, and correspondingly also the ethanol concentration was a bit lower.

\section{Conclusions}

The conditions favoring a more efficient cellulose conversion also favor desorption of the enzymes, allowing easy enzyme recovery by recycling the liquid fraction. Ultrafiltration allows the recovery of the soluble enzyme with a yield of about $80 \%$, in the lab scale trials. Operating at a temperature which does not compromise the enzyme stability is absolutely essential concerning recycling. Even when reaching high conversion degrees, still a relevant amount of enzyme remains attached to the final residue (at least 20-30\%). Finally, as an overall conclusion: enzyme recycling is certainly a possibility requiring demonstration in larger scale trials.

\section{Acknowledgements}

The authors acknowledge funding through FP7 KACELLE (Kalundborg Cellulosic Ethanol) project for supporting this work. We also thank Dr ${ }^{\mathrm{a}}$. Lucília Domingues for supplying the yeast Saccharomyces cerevisiae CEN PK 113 wild type.

\section{References}

Adney, B., Baker, J., 1996. Measurement of Cellulase Activities. Laboratory Analytical Procedure NREL/TP-510-42628. National Renewable Energy Laboratory, Golden, CO.

Bailey, M.J., Tähtiharju, J., 2003. Efficient cellulose production by Trichoderma reesei in continuous cultivation on lactose medium with a computer-controlled feeding strategy. Appl. Microbiol. Biotechnol. 62, 156-162.

Browning, B.L., 1967. In: Browning, B.L. (Ed.), Methods of Wood Chemistry. Wiley, New York.

Chylenski, P., Felby, C., Haven, M.Ø., Gama, M., Selig, M.J., 2012. Precipitation of Trichoderma reesei commercial cellulose preparations under standard enzymatic hydrolysis conditions for lignocelluloses. Biotechnol. Lett. 34, 1475-1482.

Desphande, M.V., Erikson, K.-E., 1984. Reutilization of enzymes for saccharification of lignocelluosic materials. Enzyme Microb. Technol. 6, 338-340.

Down, N., McMillan, J., 2001. SSF Experimental Protocols - Lignocellulosic Biomass Hydrolysis and Fermentation. NREL Analytical Procedure. National Renewable Energy Laboratory, Golden, CO, USA.

Girard, D.J., Converse, A.O., 1993. Recovery of cellulose from lignaceous hydrolysis residue. Appl. Biochem. Biotechnol. 39, 521-533.

Gunjikar, T.P., Sawant, S.B., Joshi, J.B., 2001. Shear deactivation of cellulase, exoglucanase, endoglucanase and $\beta$-glucosidase in mechanically agitated reactor. Biotechnol. Progr. 17, 1166-1168.

Klein-Marcusschamer, D., Oleskowicz-Popiel, P., Simmons, B.A., Blanch, W.H., 2012. The challenge of enzyme cost in the production of lignocellulosic biofuels. Biotechnol. Bioeng. 109, 1083-1089.

Knutsen, J.S., Davis, R.H., 2004. Cellulase retention and sugar removal by membrane ultrafiltration during lignocellulosic biomass hydrolysis. Appl. Biochem. Biotechnol., 585-599.

Kumar, L., Chandra, R., Saddler, J.N., 2011. Influence of steam pretreatment severity on post-treatments used to enhance the enzymatic hydrolysis of pretreated softwoods at low enzyme loadings. Biotechnol. Bioeng. 108, 2300-2311.

Lee, D., Yu, A.H.C., Saddler, J.N., 1995. Evaluation of cellulase recycling strategies for the hydrolysis of lignocellulosic substrates. Biotechnol. Bioeng. 45, 328-336.
Lindedam, J., Haven, M., Chylenski, P., Jørgensen, H., Felby, C., 2013. Recycling cellulases for cellulosic ethanol production at industrial relevant conditions: potential and temperature dependency at high solid processes. Bioresour. Technol. 148, 180-188.

Lynd, L.R., Laser, M.S., Bransby, D., Dale, B.E., Davidson, B., Hamilton, R., Himmel, M., McMillan, J.D., Sheehan, J., Wyman, C.E., 2008. How biotech can transform biofuels. Nat. Biotechnol. 26, 169-172.

Miller, G.L., 1959. Use of dinitrosalicylic acid reagent for determination of reducing sugar. Anal. Chem. 31, 426-442.

Otter, D.E., Munro, P.A., Scott, G.K., Geddes, R., 1984. Elution of Trichoderma reesei cellulase from cellulose by $\mathrm{pH}$ adjustment with sodium hydroxide. Biotechnol. Lett. 6, 369-374.

Otter, D.E., Munro, P.A., Scott, G.K., Geddes, R. 1989. Desorption of Trichoderma reesei cellulose from cellulose by a range of desorbents. Biotechnol. Bioeng. 34, 291-298.

Petersen, M.Ø., Larsen, J., Thomsen, M.H., 2009. Optimization of hydrothermal pretreatment of wheat straw for production of bioethanol at low water consumption without addition of chemicals. Biomass Bioenergy 33, 834840 .

Pribowo, A., Arantes, V., Saddler, J.N., 2012. The adsorption and enzyme activity profiles of specific Trichoderma reesei cellulose/xylanase components when hydrolysing steam pretreated corn stover. Enzyme Microb. Technol. 50, 195203.

Qi, B., Chen, X., Su, Y., Wan, Y., 2011. Enzyme adsorption and recycling during hydrolysis of wheat straw lignocelluloses. Bioresour. Technol. 102, 2881-2889.

Rad, B.L., Yazdanparast, R., 1998. Desorption of the cellulose systems of Trichoderma reesei and a Botrytis sp. from Avicel. Biotechnol. Tech. 12, 693-696.

Rodrigues, A.C., Leitão, A.F., Moreira, S., Felby, C., Gama, M., 2012. Recycling of cellulases in lignocellulosic hydrolysates using alkaline elution. Bioresour. Technol. 110, 526-533.

Seo, D.-J., Fujita, H., Sakoda, A., 2011. Effects of a non-ionic surfactant, Tween 20, on adsorption/desorption of saccharification enzymes onto/from lignocelluloses and saccharification rate. Adsorption 17, 813-822.

Sipos, B., Dienes, D., Schleicher, Á., Perazzini, R., Crestini, C., Siika-aho, M., Réczey, K., 2010. Hydrolysis efficiency and enzyme adsorption on steam-pretreated spruce in the presence of poly(ethylene glycol). Enzyme Microb. Technol. 47, 84-90.

Tengborg, C., Galbe, M., Zacchi, G., 2001. Influence of enzyme loading and physical parameters on the enzymatic hydrolysis of steam-pretreated softwood. Biotechnol. Progr. 17, 110-117.

Tu, M., Chandra, R.P., Saddler, J.N., 2007a. Evaluating the distribution of cellulases and the recycling of free cellulases during the hydrolysis of lignocellulosic substrates. Biotechnol. Progr. 23, 398-406.

Tu, M., Chandra, R.P., Saddler, J.N., 2007b. Recycling cellulases during the hydrolysis of steam exploded and ethanol pretreated Lodgepole pine. Biotechnol. Progr. 23, $1130-1137$.

Tu, M., Zhang, X., Paice, M., MacFarlane, P., Saddler, J.N., 2009. The potential of enzyme recycling during the hydrolysis of a mixed softwood feedstock. Bioresour. Technol. 100, 6407-6415.

van Tilbeurgh, H., Claeyssens, M., De Bruyne, C.K., 1982. The use of 4methylumbelliferyl and other chromophoric glycosides in the study of cellulolytic enzymes. FEBS Lett. 149, 152-156.

Wang, Q.Q., Zhu, J.Y., Hunt, C.G., Zhan, H.Y., 2012. Kinetics of adsorption, desorption, and re-adsorption of commercial endoglucanase in lignocellulosic suspensions. Biotechnol. Bioeng. 109, 1965-1975.

Wu, J.C., Ng, K.R., Chong, J., Yang, K.J., Lam, X.P., Nam, C.T., Nugroho, A.J., 2010. Recovery of cellulases by adsorption/desorption using cation exchange resins. Korean J. Chem. Eng. 27, 469-473.

Yang, J., Zhang, X., Yong, Q., Yu, S., 2010. Three-stage hydrolysis to enhance enzymatic saccharification of steam-exploded corn stover. Bioresour. Technol. 101, 4930-4935.

Ye, Z., Hatfield, K.M., Berson, R.E., 2012. Deactivation of individual cellulose components. Bioresour. Technol. 106, 133-137.

Zhu, J., Pan, X., Wang, G., Gleisner, R., 2009a. Sulfite pretreatment (SPORL) for robust enzymatic saccharification of spruce and red pine. Bioresour. Technol. 100, 2411-2418.

Zhu, Z., Sathitsuksanoh, N., Zhang, Y.-H.P., 2009. Direct quantitative determination of adsorbed cellulase on lignocellulosic biomass with its application to study cellulose desorption for potential recycling. Analyst 134, 2267-2272. 